[Chem. Pharm. Bull.

35( 1 ) $211-216(1987)]$

\title{
Structure-Activity Relationship of Brassinosteroids with Respect to the A/B-Ring Functional Groups ${ }^{1)}$
}

\author{
Suguru Takatsuto, ${ }^{*, a}$ Nobuo IKeKawa, ${ }^{b}$ Tadashi Morishita, ${ }^{c}$ \\ and Hiroshi $\mathrm{ABE}^{c}$ \\ Department of Chemistry, Joetsu University of Education, " Joetsu, Niigata 943, Japan, \\ Department of Chemistry, Tokyo Institute of Technology, ${ }^{b}$ Ookayama, Meguro-ku, \\ Tokyo 152, Japan, and Department of Plant Protection, Tokyo University \\ of Agriculture and Technology, ${ }^{C}$ Fuchu-shi, Tokyo 183, Japan
}

(Received July 25, 1986)

\begin{abstract}
In order to examine the biological role of the A/B-ring functional groups of plant-growthpromoting brassinosteroids, twenty-three brassinosteroids with some modifications at rings $\mathrm{A}$ and B $(1-15$ and $22-29)$ were bioassayed by means of the rice-lamina inclination test. The results showed that 1) removal of one or two hydroxyl groups from the A-ring reduced the biological activity of the steroids; 2) the 7-oxalactone brassinosteroids were almost as active as the corresponding 6-oxo steroids and they were much more active than their regioisomeric 6oxalactone counterparts; 3 ) introduction of a double bond at the C-7 position and a hydroxyl group at the C-5 position of 6-oxo brassinosteroids significantly decreased the biological activity of the hormonal steroids. These data suggest that the presence of a $2 \alpha, 3 \alpha$-diol, 7-oxalactone or 6 -oxo group, and the A/B-trans ring junction are important for high biological activity.
\end{abstract}

Keywords_-plant growth promoter; brassinosteroid; structure-activity relationship; ricelamina inclination test

\section{Introduction}

Since the discovery of brassinolide as a new plant growth promoter, a number of related steroids have been isolated and identified in higher plants. ${ }^{2)}$ These steroids and their synthetic analogues (termed brassinosteroids) constitute a new class of plant growth promoters. Recently, our group and the USDA scientists have independently investigated the structureactivity relationship of brassinosteroids with particular emphasis on the 22,23-vicinal diol and the 24-alkyl group, and disclosed some stringent structural requirements for high activity. ${ }^{3)}$

However, little is known about the importance of the A/B ring functional groups of the steroids. Wada et al. have examined this point by employing several brassinosteroids with the unnatural $(22 S, 23 S)$-stereochemistry in the side chain. ${ }^{4)}$ To obtain further insight into the structural requirements for the $\mathrm{A} / \mathrm{B}$ ring part, we have synthesized fifteen $(22 R, 23 R)$-28homobrassinosteroids $\left.(\mathbf{1}-\mathbf{1 5})^{5}\right)$ (Fig. 1) and four new 24-epibrassinosteroids (22-25) (Fig. 2). In this paper we report the structure-activity relationship of these brassinosteroids with respect to the A/B-ring functional groups examined by means of the rice-lamina inclination test.

\section{Experimental}

Melting points were determined on a hot stage microscope and are uncorrected. Proton nuclear magnetic resonance $\left({ }^{1} \mathrm{H}-\mathrm{NMR}\right)$ spectra were recorded on a Hitachi R-24A $(60 \mathrm{MHz})$ spectrometer with tetramethylsilane as an internal standard. Mass spectra (MS) were taken with a Shimadzu LKB-9000S mass spectrometer at $70 \mathrm{eV}$. Ultraviolet (UV) spectra were run with a Shimadzu UV-200 double beam spectrophotometer. Column chromatography was 


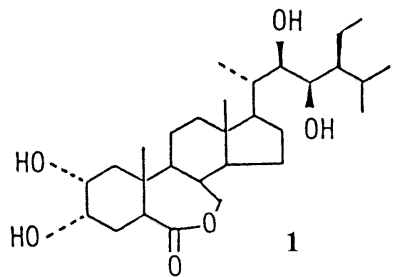

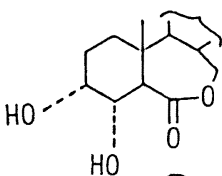

2<smiles>CC12CC[C@@H](O)CC1C(=O)OC1CC3CC(C1)C32C</smiles><smiles>CC12CCC(O)CC1C(=O)OC1C3CCC4(C)C(=O)C2CC314</smiles><smiles>CC12CCC(=O)CC1C(=O)OC1CCCC12</smiles><smiles>CC12CCCCC1C(=O)OC1CC3CCCC2C31</smiles>

6<smiles>CC12CCCCC1C(=O)CC1CCCC12</smiles>

11<smiles>CC1CC2C(=O)CC3CCC3C2(C)CC1O</smiles><smiles>CC12CC3CC4CC(=O)OC(C[C@H](O)C(O)C41)C3C2</smiles><smiles>CC12CCC(O)CC1C(=O)CC1CCCC12</smiles><smiles>CC1C(O)CCC2(C)C3OC(=O)CC4CCC(C43)C12</smiles><smiles>CC12CCC(O)CC1C(=O)CC1CCCC12</smiles><smiles>O=C1CC2CCCC2C2(O)CC[C@@H](O)CC2O1</smiles><smiles>CC12CCC(=O)CC1C(=O)CC1CCCC12</smiles><smiles>CC12CCC3CCC4CC(O)(O)CC1OC(=O)C3C42</smiles>

Fig. 1

effected with silica gel (Merck, Kieselgel 60, 70-230 mesh), and preparative and analytical thin layer chromatographies (TLC) were carried out on precoated silica gel plates (Merck, Kieselgel $60 \mathrm{~F}_{254}, 0.25 \mathrm{~mm}$ thickness). Work-up refers to dilution with water, extraction with the organic solvent indicated in parenthesis, washing of the extract to neutrality, drying over anhydrous $\mathrm{MgSO}_{4}$, filtration, and removal of the solvent under reduced pressure.

(22E,24R)-5 $\alpha$-Hydroxyergosta-2, 7,22-trien-6-one (20) - The known (22E,24R)-3 $\beta$-acetoxy- $5 \alpha$-hydroxyergosta7,22-dien-6-one $\left.(\mathbf{1 6})^{6}\right)(1.17 \mathrm{~g}, 2.49 \mathrm{mmol})$ in tetrahydrofuran (THF, $\left.50 \mathrm{ml}\right)$ was treated with $5 \% \mathrm{KOH} / \mathrm{MeOH}(10 \mathrm{ml})$ at room temperature for $1 \mathrm{~h}$. Work-up $\left(\mathrm{CH}_{2} \mathrm{Cl}_{2}\right)$ and recrystallization from EtOAc gave the $3 \beta, 5 \alpha$-diol $17(439 \mathrm{mg})$. The mother liquor was concentrated and chromatographed on silica gel $(40 \mathrm{~g})$ with $\mathrm{CHCl}_{3}-\mathrm{MeOH}(20: 1)$ to give additional diol $17(240 \mathrm{mg})$. The total amount of 17 was $679 \mathrm{mg}\left(64^{\circ}\right), \mathrm{mp} 252-253^{\circ} \mathrm{C}$ (EtOAc). UV $\lambda_{\max }^{\mathrm{EtOH}}: 248 \mathrm{~nm}$. ${ }^{1} \mathrm{H}-\mathrm{NMR}\left(\mathrm{CDCl}_{3}\right) \delta: 0.68\left(3 \mathrm{H}, \mathrm{s}, 18-\mathrm{H}_{3}\right), 0.86\left(3 \mathrm{H}, \mathrm{s}, 19-\mathrm{H}_{3}\right), 3.90(1 \mathrm{H}, \mathrm{m}, 3-\mathrm{H}), 5.20(2 \mathrm{H}, \mathrm{m}, 22-\mathrm{H}$ and $23-\mathrm{H}), 5.62$ $(1 \mathrm{H}, \mathrm{m}, 7-\mathrm{H})$. The diol $17(626 \mathrm{mg}, 1.46 \mathrm{mmol})$ in pyridine $(10 \mathrm{ml})$ was treated with $p$-toluenesulfonyl chloride ( $800 \mathrm{mg}, 4.2 \mathrm{mmol})$ at room temperature overnight. Work-up (EtOAc) gave the tosylate $18(828 \mathrm{mg}$ ), which was further treated with lithium carbonate $(400 \mathrm{mg}, 5.41 \mathrm{mmol})$ and dimethylformamide $(10 \mathrm{ml})$ at $150^{\circ} \mathrm{C}$ for $45 \mathrm{~min}$. Work-up (EtOAc) and chromatography on silica gel $(50 \mathrm{~g})$ with benzene-EtOAc $(80: 1)$ gave the trienone $20(227 \mathrm{mg}$, $38 \%$ ), mp 204-205 ${ }^{\circ} \mathrm{C}(\mathrm{MeOH})$. UV $\lambda_{\max }^{\mathrm{EIOH}}: 248 \mathrm{~nm}(\varepsilon 11500) .{ }^{1} \mathrm{H}-\mathrm{NMR}\left(\mathrm{CDCl}_{3}\right) \delta: 0.70\left(3 \mathrm{H}, \mathrm{s}, 18-\mathrm{H}_{3}\right), 0.87(3 \mathrm{H}, \mathrm{s}$, $\left.19-\mathrm{H}_{3}\right), 5.20(2 \mathrm{H}, \mathrm{m}, 22-\mathrm{H}$ and $23-\mathrm{H}), 5.68(3 \mathrm{H}, \mathrm{m}, 2-\mathrm{H}, 3-\mathrm{H}$, and $7-\mathrm{H})$. Anal. Calcd for $\mathrm{C}_{28} \mathrm{H}_{42} \mathrm{O}_{2}: \mathrm{C}, 81.90 ; \mathrm{H}, 10.31$. Found: C, 82.19; $\mathrm{H}, 10.26$.

(22E,24R)-5 $\alpha$-Ergosta-2,7,22-trien-6-one (21) - The known (22E, 24R)-3 $\beta$-acetoxy-5 $\alpha$-ergosta-7,22-dien-6-one $(5 \mathrm{a})^{6}(1.8 \mathrm{~g}, 3.96 \mathrm{mmol})$ was transformed, as described for 16, into the trienone $21(455 \mathrm{mg}, 41 \%), \mathrm{mp} 138-140^{\circ} \mathrm{C}$ $(\mathrm{MeOH})$. UV $\lambda_{\max }^{\text {EOH }}: 244 \mathrm{~nm}(\varepsilon 11100) .{ }^{1} \mathrm{H}-\mathrm{NMR}\left(\mathrm{CDCl}_{3}\right) \delta: 0.89\left(3 \mathrm{H}, \mathrm{s}, 18-\mathrm{H}_{3}\right), 1.00\left(3 \mathrm{H}, \mathrm{s}, 19-\mathrm{H}_{3}\right), 5.25(2 \mathrm{H}, \mathrm{m}, 22-$ $\mathrm{H}$ and $23-\mathrm{H}), 5.65\left(2-\mathrm{H}, \mathrm{m}, 2-\mathrm{H}\right.$ and 3-H), $5.83(1 \mathrm{H}, \mathrm{d}, J=3 \mathrm{~Hz}, 7-\mathrm{H})$. Anal. Calcd for $\mathrm{C}_{28} \mathrm{H}_{42} \mathrm{O}: \mathrm{C}, 85.22 ; \mathrm{H}, 10.73$. Found: C, $85.10 ; \mathrm{H}, 10.77$.

$(22 R, 23 R, 23 R)$ - and $(22 S, 23 S, 24 R)-2 \alpha, 3 \alpha, 5 \alpha, 22,23-P e n t a h y d r o x y e r g o s t-7-e n-6-o n e ~(22$ and 23$)$ - The trienone $20(251 \mathrm{mg}, 0.611 \mathrm{mmol})$ in tert $-\mathrm{BuOH}-\mathrm{THF}-\mathrm{H}_{2} \mathrm{O}(10: 3: 1,10 \mathrm{ml})$ was treated with osmium tetroxide $(20 \mathrm{mg})$ and $N$ methylmorpholine $\mathrm{N}$-oxide $(420 \mathrm{mg}, 3.11 \mathrm{mmol})$ at room temperature for $63 \mathrm{~h}$. Work-up $\left(\mathrm{CH}_{2} \mathrm{Cl}_{2}\right)$ gave crude products $(290 \mathrm{mg})$, which showed two main spots on TLC $\left(\mathrm{CHCl}_{3}-\mathrm{MeOH}, 10: 1\right.$, developed twice) with $R f$ values of 0.26 and 0.20 . These two products were purified by preparative TLC $\left(\mathrm{CHCl}_{3}-\mathrm{MeOH}, 10: 1\right.$, developed three times $)$ to give the less polar $(22 S, 23 S)$-pentaol $23(75 \mathrm{mg}, 26 \%), \mathrm{mp} 229-231^{\circ} \mathrm{C}$ (dec., EtOAc), UV $\lambda_{\max }^{\mathrm{EtOH}}: 248 \mathrm{~nm}(\varepsilon 11100)$, ${ }^{1} \mathrm{H}-\mathrm{NMR}\left(\mathrm{CDCl}_{3}-\mathrm{CD}_{3} \mathrm{OD}\right) \delta: 0.72\left(3 \mathrm{H}, \mathrm{s}, 18-\mathrm{H}_{3}\right), 0.88\left(3 \mathrm{H}, \mathrm{s}, 19-\mathrm{H}_{3}\right), 5.70(1 \mathrm{H}, \mathrm{m}, 7-\mathrm{H})$, Anal. Calcd for $\mathrm{C}_{28} \mathrm{H}_{46} \mathrm{O}_{6}$ : C, 70.26; H, 9.69. Found: C, 70.09; H, 9.81, and the more polar $(22 R, 23 R)$-pentaol $22(68 \mathrm{mg}, 23 \%), \mathrm{mp} 245-246^{\circ} \mathrm{C}$ 
<smiles>[R20]C1CCC2(C)C3CCC4(C)C3CCC(C(C)/C=C/C(C)C(C)C)C4C3=CC(=O)C(O)(CC3)C2C1</smiles>

$16: R=A C$

$17: R=H$

$18: R=T S$

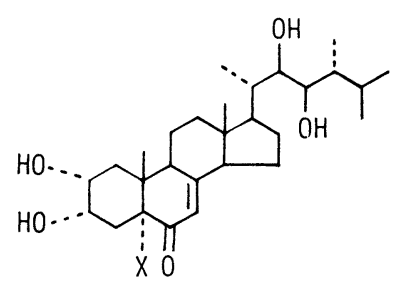

$$
22: X=O H
$$$$
24: X=H
$$

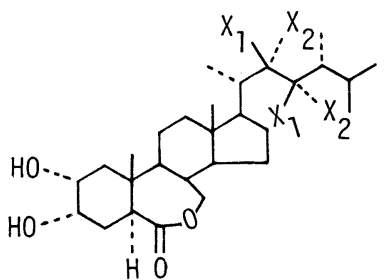

$$
\begin{aligned}
& \text { 26: } x_{1}=O H, X_{2}=H \\
& 27: x_{1}=H, x_{2}=O H
\end{aligned}
$$<smiles>[Y]C12CCCC1C1CCC3C(CCC(C(C)C=CC(C)C(C)C)C4([X])CC=CCC34C)C1=CC2=O</smiles>

20: $X=\mathrm{OH}$

21: $X=H$

19<smiles>[X]C12CCC3C4=CC(=O)C5(C(C)C(O)C(O)C(C)C(C)C)CCC5C4(C)CCC3C1(C)CC(O)C(O)C2</smiles>

23: $\mathrm{X}=\mathrm{OH}$

25: $X=H$

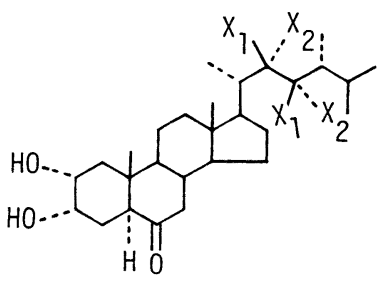

28: $X_{1}=\mathrm{OH}, X_{2}=H$
$29: X_{1}=H, X_{2}=O H$

Fig. 2

(EtOAc), UV $\lambda_{\max }^{\mathrm{EtOH}:} 248 \mathrm{~nm}(\varepsilon 11100),{ }^{1} \mathrm{H}-\mathrm{NMR}\left(\mathrm{CDCl}_{3}-\mathrm{CD}_{3} \mathrm{OD}\right) \delta: 0.71\left(3 \mathrm{H}, \mathrm{s}, 18-\mathrm{H}_{3}\right), 0.87\left(3 \mathrm{H}, \mathrm{s}, 19-\mathrm{H}_{3}\right), 5.68$ $(1 \mathrm{H}, \mathrm{m}, 7-\mathrm{H})$, Anal. Calcd for $\mathrm{C}_{28} \mathrm{H}_{46} \mathrm{O}_{6}: \mathrm{C}, 70.26 ; \mathrm{H}, 9.69$. Found: C, 70.12; $\mathrm{H}, 9.72$.

$(22 R, 23 R, 24 R)$ - and $(22 S, 23 S, 24 R)-2 \alpha, 3 \alpha, 22,23$-Tetrahydroxy-5 $\alpha$-ergost-7-en-6-one (24 and 25$)$ - The trienone $21(201 \mathrm{mg}, 0.509 \mathrm{mmol})$ was hydroxylated with osmium tetroxide, as described for 20 , to give the less polar $(22 S, 23 S)$-tetraol 25 (42 mg, 18\%), amorphous solid, UV $\lambda_{\max }^{\mathrm{EtOH}}: 244 \mathrm{~nm}(\varepsilon 11100),{ }^{1} \mathrm{H}-\mathrm{NMR}\left(\mathrm{CDCl}_{3}-\mathrm{CD}_{3} \mathrm{OD}\right) \delta$ : $0.71\left(3 \mathrm{H}, \mathrm{s}, 18-\mathrm{H}_{3}\right), 5.82(1 \mathrm{H}, \mathrm{m}, 7-\mathrm{H})$, and the more polar $(22 R, 23 R)$-tetraol $24(40 \mathrm{mg}, 17 \%), \mathrm{mp} 250-251^{\circ} \mathrm{C}$ (EtOAc), UV $\lambda_{\max }^{\mathrm{EIOH}}: 244 \mathrm{~nm}(\varepsilon 11100),{ }^{1} \mathrm{H}-\mathrm{NMR}\left(\mathrm{CDCl}_{3}-\mathrm{CD}_{3} \mathrm{OD}\right) \delta: 0.72\left(3 \mathrm{H}, \mathrm{s}, 18-\mathrm{H}_{3}\right), 5.82(1 \mathrm{H}, \mathrm{m}, 7-\mathrm{H})$. Gas chromatography-mass spectrometry (GC-MS) analysis of the bismethaneboronates ${ }^{7)}$ of 24 and 25 was carried out; Shimadzu LKB 9000S; column, $1 \%$ OV-17 (3 mm i.d. $\times 1 \mathrm{~m})$; column temp., $280^{\circ} \mathrm{C}$, carrier gas, helium; flow rate, $30 \mathrm{ml} / \mathrm{min}$. The retention times of the bismethaneboronates of 24 and 25 were 17.0 and $15.5 \mathrm{~min}$, respectively. Electron impact-mass spectra (EI-MS) of the bismethaneboronates of $\mathbf{2 4}$ and $\mathbf{2 5}$ were identical and were as follows; $m / z 510\left(\mathrm{M}^{+}, 23 \%\right), 495(6), 468(13), 450(4), 439(3), 411(5), 397(10), 367$ (7), $356(6), 355(6), 327(29), 301$ (42), 285 (6), 233 (15), 155 (36), 95 (100), 85 (68), 71 (39), 43 (88).

It is well known that upon osmium tetroxide oxidation of a $5 \alpha$-2-ene steroid, the bulky osmium tetroxide approaches stereoselectively from the less hindered $\alpha$-face to afford the $2 \alpha, 3 \alpha$-diol steroid. ${ }^{8)}$ However, the stereochemical assignment of $\mathbf{2 2}, \mathbf{2 3}, \mathbf{2 4}$, and $\mathbf{2 5}$ at the C-22,23 position was only tentative, based on the mobilities on TLC. Many examples have been reported showing that $(22 S, 23 S)$-brassinosteroids are less polar than their $(22 R, 23 R)$-stereoisomers on normal-phase TLC. ${ }^{3 e f)}$

Brassinosteroids—-The $(22 R, 23 R)$-28-homobrassinosteroids $\mathbf{1}-\mathbf{1 5}$ and the 24-epibrassinosteroids $\mathbf{2 6}-\mathbf{2 9}$ were prepared as described in our previous papers. ${ }^{5,9)}$

Rice-Lamina Inclination Test-The bioassay was carried out according to the reported method ${ }^{3 a)}$ using 
etiolated seedlings of rice (Oryza sativa L. cv Arborio J1).

\section{Results and Discussion}

For the investigation of the importance of the A/B-ring functionalities of brassinosteroids, fifteen $(22 R, 23 R, 24 S)$-28-homobrassinosteroids with modifications at rings $\mathrm{A}$ and $\mathrm{B}$ were synthesized as described in our previous paper. ${ }^{5)}$ They have the same stereochemistry in the side chain that brassinolide has. The bioassay was carried out using the rice-lamina inclination test, which was originally developed as an auxin bioassay system and has recently been found to be a highly sensitive and specific bioassay for brassinosteroids. ${ }^{3 a, 4)}$ The results are summarized in Table I. 28-Homobrassinolide (1), having the same activity as brassinolide in this bioassay, ${ }^{3 a)}$ was used as a standard compound and 28 -homobrassinolide (1), giving $c a$. $140^{\circ}$ bending angle between laminae and sheaths at $0.01 \mu \mathrm{g} / \mathrm{ml}$, showed the strongest activity among the 28 -homobrassinosteroids tested. The tetrahydroxy steroid 2 having a $3 \alpha, 4 \alpha$-diol moiety instead of $2 \alpha, 3 \alpha$-diol was slightly less active than 28 -homobrassinolide (1), judging from the concentration giving $c a .140^{\circ}$ bending angle. The 2 -deoxy-3 $\alpha$-hydroxylactone 3

TABLE I. Activities of 28-Homobrassinosteroids in the Rice-Lamina Inclination Test

\begin{tabular}{ccccccccc}
\hline \hline \multirow{8}{*}{$\begin{array}{c}\text { Concentration } \\
(\mu \mathrm{g} / \mathrm{ml})\end{array}$} & $\mathbf{1}$ & $\mathbf{2}$ & $\mathbf{3}$ & $\mathbf{4}$ & $\mathbf{5}$ & $\mathbf{6}$ & $\mathbf{7}$ & $\mathbf{8}$ \\
\cline { 2 - 9 } & & 180 & & 180 & & 180 & 180 & 180 \\
10 & 180 & $163 \pm 13$ & $171 \pm 15$ & $149 \pm 9$ & 180 & $164 \pm 23$ & 180 & $165 \pm 21$ \\
1 & 180 & $169 \pm 11$ & $128 \pm 16$ & $138 \pm 19$ & $127 \pm 5$ & $127 \pm 5$ & $173 \pm 9$ & $141 \pm 12$ \\
0.1 & $142 \pm 17$ & $119 \pm 17$ & $120 \pm 19$ & $101 \pm 11$ & $114 \pm 11$ & $99 \pm 3$ & $144 \pm 23$ & $123 \pm 15$ \\
0.01 & $129 \pm 16$ & $117 \pm 9$ & $120 \pm 9$ & $100 \pm 11$ & $97 \pm 10$ & $102 \pm 18$ & $126 \pm 10$ & $121 \pm 12$ \\
0.001 & $102 \pm 16$ & & & & & & & \\
Control & & & & & & & & \\
\hline
\end{tabular}

\begin{tabular}{cccccccc}
\hline \hline \multirow{2}{*}{$\begin{array}{c}\text { Concentration } \\
(\mu \mathrm{g} / \mathrm{ml})\end{array}$} & $\mathbf{9}$ & $\mathbf{1 0}$ & $\mathbf{1 1}$ & $\mathbf{1 2}$ & $\mathbf{1 3}$ & $\mathbf{1 4}$ & $\mathbf{1 5}$ \\
\cline { 2 - 8 } & & 180 & $144 \pm 8$ & 180 & $163 \pm 15$ & 180 & 180. \\
10 & 180 & $138 \pm 20$ & $113 \pm 15$ & 180 & $140 \pm 23$ & $161 \pm 13$ & $154 \pm 10$ \\
1 & $146 \pm 11$ & $103 \pm 9$ & $118 \pm 11$ & $117 \pm 19$ & $130 \pm 13$ & $120 \pm 10$ & $114 \pm 12$ \\
0.1 & $118 \pm 11$ & $100 \pm 13$ & $109 \pm 17$ & $117 \pm 18$ & $110 \pm 11$ & $117 \pm 11$ & $124 \pm 11$ \\
0.01 & $119 \pm 14$ & $94 \pm 6$ & $105 \pm 9$ & $109 \pm 12$ & $100 \pm 14$ & $117 \pm 12$ & $115 \pm 15$ \\
0.001 & $102 \pm 16$ & & & & & & \\
Control & & & & & & & \\
\hline
\end{tabular}

\begin{tabular}{|c|c|c|c|c|c|c|c|c|}
\hline \multirow{2}{*}{$\begin{array}{l}\text { Concentration } \\
(\mu \mathrm{g} / \mathrm{ml})\end{array}$} & \multicolumn{8}{|c|}{ Compounds } \\
\hline & 26 & 27 & 28 & 29 & 22 & 23 & 24 & 25 \\
\hline 10 & & & & & $135 \pm 6$ & $114 \pm 10$ & 180 & $144 \pm 12$ \\
\hline 1 & 180 & & 180 & 180 & $106 \pm 7$ & $101 \pm 6$ & $170 \pm 11$ & $110 \pm 4$ \\
\hline 0.1 & $159 \pm 5$ & 180 & $175 \pm 9$ & $140 \pm 18$ & $109 \pm 8$ & $93 \pm 2$ & $136 \pm 22$ & $107 \pm 7$ \\
\hline 0.01 & $139 \pm 2$ & $131 \pm 2$ & $146 \pm 11$ & $105 \pm 10$ & $98 \pm 6$ & & $117 \pm 12$ & \\
\hline 0.001 & $121 \pm 12$ & $100 \pm 1$ & $128 \pm 7$ & $104 \pm 5$ & & & & \\
\hline Control & $97 \pm 5$ & & & & & & & \\
\hline
\end{tabular}

Values in the table are angles (in degrees) between the lamina and sheath ( \pm standard error). 
showed almost the same activity as its $3 \beta$-isomer $\mathbf{4}$ and they were about one-tenth as active as the standard $\mathbf{1}$, indicating that the hydroxyl group at $2 \alpha$-position is not indispensable to elicit the biological activity, although its absence reduced the activity. It is of interest that the 3ketolactone 5 and the 2,3-dideoxylactone 6 possessed $\mathrm{ca} .5 \%$ of the activity of the native steroidal lactone 1. Among the 6-oxo steroids, the 28 -homologue 7 of castasterone induced the strongest response, the activity being almost equal to that of 28 -homograssinolide (1). The $3 \alpha$ - and $3 \beta$-hydroxy ketones $\mathbf{8}$ and $\mathbf{9}$ were equally active and were about one-tenth as active as the reference steroid $\mathbf{1}$. These ketones have similar activity to the corresponding 7-oxalactones 3 and $\mathbf{4}$. The 3-keto steroid 10 was $c a$. 10 times less active than the corresponding $3 \alpha-$ and $3 \beta$ hydroxy steroids 8 and 9 . The activity of the 2,3-dideoxy ketone 11 was $c a .100$ times less than that of the 2,3-dideoxylactone $\mathbf{6}$, suggesting that the 7-oxalactone group plays a more important role in the plant growth-promoting activity than the 6-oxo group. In the case of 28homocastasterone (7), it may bind to the receptor as effectively as 28 -homobrassinolide (1) and may be rapidly metabolized to the corresponding lactone $\mathbf{1}$, exhibiting high biological activity. The regioisomeric 6-oxalactone compounds $\mathbf{1 2}$ and $\mathbf{1 3}$ were found to be less active than the corresponding 7-oxalactones 1 and 2, respectively, indicating that the 7-oxalactone group in the B-ring, as in brassinolide, cannot be replaced by the 6-oxalactone group. However, it is interest to note that the 2-deoxy 6-oxalactones 14 and 15 were almost as active as the 2-deoxy 7-oxalactone counterparts 3 and $\mathbf{4}$, respectively.

The biological activity of the new 24-epibrassinosteroids $\mathbf{2 2}-\mathbf{2 5}$ prepared in this paper was also evaluated by using the rice-lamina inclination test. The results are summarized in Table I, along with the biological results for 24-epibrassinolide (26), 24-epicastasterone (28), and their $(22 S, 23 S)$-stereoisomers 27, and 29. 24-Epibrassinolide (26), giving ca. $140^{\circ}$ bending angle at $0.01 \mu \mathrm{g} / \mathrm{ml}$, was several times more active than the $(22 S, 23 S)$-lactone stereoisomer 27. 24-Epicastasterone (28) was found to be as highly active as 24 -epibrassinolide (26), while its $(22 S, 23 S)$-stereoisomer 29 was about ten times less active than the corresponding lactone 27. These relations are in good agreement with our previous findings, in which a number of brassinosteroids with modified side chains were bioassayed by using the rice-lamina inclination test. $^{3 a)}$

It is of interest that the $(22 R, 23 R)$-7-en-6-one compound $\mathbf{2 4}$, which has an additional double bond at the $\mathrm{C}-7$ position, gave $c a .140^{\circ}$ bending angle at $0.1 \mu \mathrm{g} / \mathrm{ml}$ and was estimated to be about ten times less active than 24-epicastasterone (28), because these two steroidal ketones could be considered to be almost identical in terms of steric and conformational factors. The $(22 R, 23 R)-5 \alpha$-hydroxyenone 22 was found to be $c a .10^{3}$ times less active than the native 24-epicastasterone (28), judging from the concentration giving $\mathrm{ca} .140^{\circ}$ bending angle. The (22S,23S)-brassinosteroids $\mathbf{2 3}$ and $\mathbf{2 5}$ were weakly active and were less active than the corresponding $(22 R, 23 R)$-stereoisomers 22 and $\mathbf{2 3}$, respectively. These results showed that introduction of a double bond at the C-7 position and a hydroxyl group at the C-5 position markedly decreased the activity of brassinosteroids.

On the other hand, Yokota et al. have recently isolated 6-deoxocastasterone, which lacks the 6-oxo functional group of castasterone, and they reported that it was $c a$. 100 times less active than castasterone in the rice-lamina inclination test. ${ }^{10)}$ Our present results and the reported data lead us to conclude that the 7-oxalactone or 6-oxo functionality, as in brassinolide or castasterone, is allowed as a B-ring functionality of brassinosteroids for high plant growth-promoting activity, in addition to the presence of the $2 \alpha, 3 \alpha$-diol in the A-ring and the $\mathrm{A} / \mathrm{B}$ trans ring junction.

\section{References and Notes}

1) A part of this work was presented at the Symposium on Chemical Regulation of Plants, Nagoya, October 1983, 
p. 26.

2) a) T. Yokota, The 20th Symposium on Phytochemistry, Tokyo, January 1983, p. 68; b) N. Ikekawa and S. Takatsuto, Mass Spectroscopy, 32, 55 (1984).

3) a) S. Takatsuto, N. Yazawa, N. Ikekawa, T. Morishita, and H. Abe, Phytochemistry, 22, 1393 (1983); b) S. Takatsuto, N. Yazawa, N. Ikekawa, T. Takematsu, T. Takeuchi, and M. Koguchi, ibid., 22, 2437 (1983); c) K. Wada, S. Marumo, K. Mori, S. Takatsuto, M. Morisaki, and N. Ikekawa, Agric. Biol. Chem., 47, 1139 (1983); d) S. Takatsuto, N. Yazawa, and N. Ikekawa, Phytochemistry, 23, 525 (1984); e) M. J. Thompson, N. B. Mandava, W. J. Meudt, W. R. Lusby, and D. W. Spaulding, Steroids, 38, 567 (1981); f) M. J. Thompson, W. J. Meudt, N. B. Mandava, S. R. Dutky, W. R. Lusby, and D. W. Spaulding, ibid., 39, 89 (1982).

4) K. Wada and S. Marumo, Agric. Biol. Chem., 45, 2579 (1981).

5) S. Takatsuto and N. Ikekawa, J. Chem. Soc., Perkin Trans. 1, 1984, 439.

6) D. H. R. Barton and C. H. Robinson, J. Chem. Soc., 1954, 3045.

7) S. Takatsuto, B. Ying, M. Morisaki, and N. Ikekawa, J. Chromatogr., 239, 233 (1982).

8) L. F. Fieser and M. Fieser, "Steroids," Reinhold, New York, 1959, p. 274.

9) S. Takatsuto and N. Ikekawa, Chem. Pharm. Bull., 32, 2001 (1984).

10) T. Yokota, M. Morita, and N. Takahashi, Agric. Biol. Chem., 47, 2149 (1983). 